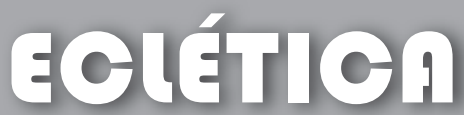 química
}

\section{A SIMPLE SPECTROPHOTOMETRIC METHOD FOR THE DETERMINATION OF CAPTOPRIL IN PHARMACEUTICAL PREPARATIONS USING AMMONIUM MOLYBDATE}

\author{
P. R. S. Ribeiro ${ }^{1 *}$, L. Pezza ${ }^{2}$, H. R. Pezza ${ }^{2}$ \\ 1. Centro de Ciências Sociais, Saúde e Tecnologia - UFMA, CEP 65900-000, Imperatriz, MA, Brazil. \\ 2. Instituto de Química - UNESP, P.O. Box 355, CEP 14801-970, Araraquara, SP, Brazil. \\ *Corresponding author. E-mail: pauloufma@ufma.br.FAX: +55-99-3524-6200
}

\begin{abstract}
A simple, rapid and sensitive spectrophotometric method for the determination of captopril (CPT) in pharmaceutical formulations is proposed. This method is based on the reduction reaction of ammonium molybdate, in the presence of sulphuric acid, for the group thiol of CPT, producing a green compound $\left(\lambda_{\max } 407 \mathrm{~nm}\right)$. Beer's law is obeyed in a concentration range of $4.60 \times 10^{-4}-1.84 \times 10^{-3} \mathrm{~mol} \mathrm{l}^{-1}$ of CPT with an excellent correlation coefficient $(r=$ $0.9995)$. The limit of detection and limit of quantification were $7.31 \times 10^{-6}$ e $2.43 \times 10^{-5} \mathrm{~mol}$ $\mathrm{l}^{-1}$ of CPT, respectively. The proposed method was successfully applied to the determination of CPT in commercial brands of pharmaceuticals. No interferences were observed from the common excipients in the formulations. The results obtained by the proposed method were favorably compared with those given by the official reported method at $95 \%$ confidence level.
\end{abstract}

Keywords: Captopril, spectrophotometric determination, ammonium molybdate.

\section{Introduction}

Captopril, 1 - [(2S)- 3 - mercapto -2 -methylpropionyl]-L-proline (Figure 1), (CPT) is an angiotensin-converting enzyme inhibitor, which reduces peripheral resistance end lowers blood pressure. It is extensively used for the treatment of hypertension [1] and congestive failure [2].

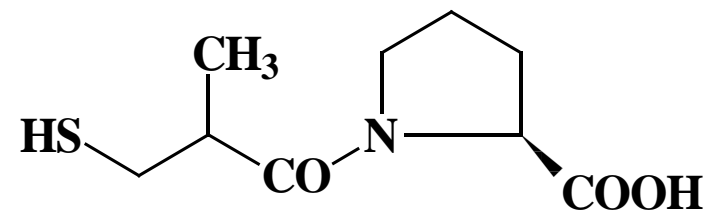

Fi ure Chemical structure of captopril.

In order to assure the quality of CPT containing pharmaceutical formulations, several methods have been developed for its determination, including batch fluorimetry [3], chemiluminescence [4 - 7], AAS [8, 9], high-performance liquid chromatography (HPLC) [10 - 17], GC [18], differential pulse polarography [19], amperometry [20 - 22], volumetric titration [23], potentiometric titration [24 - 28], capillary electropho- 
resis [29], conductometry [30], coulometry [31], voltammetry [32] and potentiometry [33].

However, batch methods are generally time-consuming and laborious. In addition, chromatographic methods are slow and require expensive and complicated instrumentation, features that make them unattractive to routine analysis. Titrimetric method has suffered from a lack of specificity and sensitivity, under certain circumstances, such as the presence of unsaturated organic compounds.

Obviously, because of its low operating costs, simple equipment, as well as the widespread use of common laboratory, spectrophotometry has been an important analytical method to the chemical workers of analysis. It is very significant to find a rapid, accurate and simple method to cant to find a rapid, accurate and simple method to cal medicine. Thus, spectrophotometric methods cal medicine. Thus, spectrophotometric methods have also been described for the determination of CPT in the pure form and in pharmaceutical formulations [27, 34 - 42]. A UV spectrophotometric procedure has been used for the determination of CPT in bulk drug and tablets in the presence of iodine, where the indirect quantization of the product was carried at $351 \mathrm{~nm}$ [34] This method present low selectivity, as all unsturated conpresent low compounds display one or more bands in that region in the area of the visible after the reaction with iodine [34], ferric chloride in presence of 2,2'bipirydil [34] and potassium ferricyanide [35], $\mathrm{Pd}(\mathrm{II})[27,36,37], \mathrm{Co}(\mathrm{II})$ in presence of $2,2^{\prime}$-dipyridil-2-pyridylhydrazone [38], N-(1-naphtyl) ethylenediamine in acid media (nitrous acid) [39], Folin-Ciocalteu reagent $[40,41]$ and molybdophosphoric acid [42]. This last procedure can only pe used for the determing ms, because the presence of the most com cipiens in phas cipients in pharmaceutical formulations (glucose, fructose, lactose, sucrose, starch) they interfere seriously in this method. Such interferences, no studied by the authors, they were confirmed starting from preliminary tests accomplished at our research laboratory. However, no spectrophotometric method for determination of CPT based on the reduction reaction of ammonium molybdate has been reported.
Salts of molybdenum (VI) have been used as oxidizing agents in the spectrophotometric determinations of a number of substances of ssayed by usi Molybdophosphoric acid has been applied in the determination of cephalosporins [45, 46], levodopa, carbidopa, $\alpha$-methyldopa, isoniazid and acetaminophen [47]. The same reagent has also been applied successfully for the determination of phenothiazines [48, 49].

In this work, we report a novel, simple, rapid, cost-effective, precise, sensitive and accurate spectrophotometric method that is ideal for routine analysis of CPT in pharmaceuticals. Additionally, the proposed technique was ascibed to the fact that they are easily and widely used in laboratory anlysis in addition to being used in laboterms of their implementation and mancal in

The proposed method is based on reaction of reduction of ammonium molybdate fo the group thiol of CPT in acid media. The measurement of absorbance is made spectrophotometrically at $407 \mathrm{~nm}$. The results agreed fairly well with those obtained by the USP standard procedure [23] at $95 \%$ confidence level. In this method, CPT has been determined by volunetric tira(itra, the thiol group throuh iodometric titration.

\section{Experimental}

\section{Apparatus}

A HP 8453 spectrophotometer with $1 \mathrm{~cm}$ matched silica cells was used for all absorbance measurements. Volume measurements were made with plunger-operated pipetters (25-250 $\mu \mathrm{L}$ and $100-1000 \mu \mathrm{L}$ ) and Metrohm model 665 and ic bure $\mu$ ) All experits thermostated room $(25 \pm 1)^{\circ} \mathrm{C}$.

\section{Reagents and solutions}

For the preparation of the solutions and samples, deionised water (conductivity $>1 \mu \mathrm{S} \mathrm{cm}$

$$
\text { Ecl. Quím., São Paulo, } 35 \text { - 3: } 179 \text { - 188, } 2010
$$

${ }^{1}$ ) or chloroform and grade A glassware were used throughout. Analytical-reagent or pharmaceutical grade chemicals were used.

Captopril (standard substance) was purchased from Purifarma, Brazil (purity > 99.9\%). Its characteristic was consistent with the USP [23].

A $4.60 \times 10^{-2} \mathrm{~mol} \mathrm{l}^{-1}\left(1000 \mathrm{mg} \mathrm{l}^{-1}\right)$ captopril stock was prepared daily by dissolving $50.0 \mathrm{mg}$ of the drug in $5.0 \mathrm{ml}$ of chloroform. Working standard solutions were obtained by appropriate dilution of this stock solution with the same solvent.

The sulphuric acid (Mallinckrodt, Xalos-

toc, Mexico) solution $8.73 \mathrm{~mol} \mathrm{l}^{-1}$ was prepared in the usual way, from the concentrated acid (96\%).

The ammonium molybdate $\left[\left(\mathrm{NH}_{4}\right)_{6} \cdot \mathrm{Mo}\right.$ $\left.\mathrm{O}_{24} \cdot 4 \mathrm{H}_{2} \mathrm{O}\right]$ (Mallinckrodt, Xalostoc, Mexico) aqueous solution $2 \%\left(\mathrm{~m} \mathrm{v}^{-1}\right)$ was prepared daily.

\section{Recommended procedure}

\section{Procedure for the calibration curve}

Transfer $300 \mu \mathrm{L}$ of captopril working standard solutions (comprising $4.60 \times 10^{-4}-1.84 \times$ $10^{-3} \mathrm{~mol} \mathrm{l}^{-1}$ of the drug) into each series of $5.0 \mathrm{ml}$ graduated flasks. Add to each graduated flask 3.00 $\mathrm{ml} 8.73 \mathrm{~mol} \mathrm{l}^{-1} \mathrm{H}_{2} \mathrm{SO}_{4}$ followed by $1.000 \mathrm{ml} 2 \%$ ammonium molybdate (under stirring). The graduated flask are loosely stoppered to room temperature $\left(25 \pm 1^{\circ} \mathrm{C}\right)$ for $30 \mathrm{~min}$. After the time, the contents were diluted to the mark with deionised water and mixed well. The blank solution is prepared in a similar way, but omitting captopril. Immediately, the absorbance each flask was measure at $407 \mathrm{~nm}$, against corresponding reagent blank. Calibration graphs prepares by plotting absorbance against drug concentration. These graphs or the corresponding linear least squares equations are used to convert tration, for any analyzed sample.

Procedure for the assay of CPT in pharmaceutical samples

For the determination of CPT in pharmaceutical samples, sixteen tablets were weighed to calculate the average tablet weight. They were finely powdered and homogenized. Equivalent to about $41.7 \mathrm{mg}$ of captopril of the powder was accurately weighed and transferred into a $10.0 \mathrm{ml}$ standard flask dissolved with approximately 7.0 ml of chlorforn and, by soicaing for 20 min 7.0 an ultrasonic bath, and he volume the same solvent. Aliquots of $300 \mu$ of supenaant liquid of this resulting of $300 \mu$ of supernaaccording to the recommended procedure.

\section{Results and discussion}

Captopril, as all thiols was expected to undergo to some extent oxidative degradation such as the formation of disulphide [50] and this suggests the investigation of an analytical procedure based on the reactivity of the thiol group, with regard to obtaining a stability indicating assay method.

It has long been know that a colour solution is obtained by reduction of an acidified solution of Mo (VI). The substances responsible for this colour are compounds in which the mean oxidation state of Mo is between $4+, 5+$ and $6+$. These compounds contain both oxides and hydroxides appear to be an entire series of "genotypic" compounds (i.e. having the same basic structure but differing in the charges on cations and anions) with $\mathrm{MoO}(\mathrm{OH})_{2}$ (green colour) as one limit and $\mathrm{MoO}_{3}$ as the other.

So, the tone of the colour of a reduced solution of Mo (VI) changes as a function of the variation of the concentration of each absorben particle, which derived from the reduction of the Mo (VI), the concentration and of the reducing strength of the used reducing agent. The captopril has been used as reducing agent due to reactivity of the thiol group of this compound.

The method involves the reaction of CPT with molybdate ions, in acidic media, to produce green product. The absorption spectrum of the reaction product (Figure 2) shows that the best analytical wavelength is located at $407 \mathrm{~nm}$. 
The Figure 3 show that a stoppered to room temperature $\left(25 \pm 1{ }^{\circ} \mathrm{C}\right)$ time of $30 \mathrm{~min}$ is required for

Thus, below this time $(30 \mathrm{~min})$ the colour intensity and the sensitivity of method diminished.

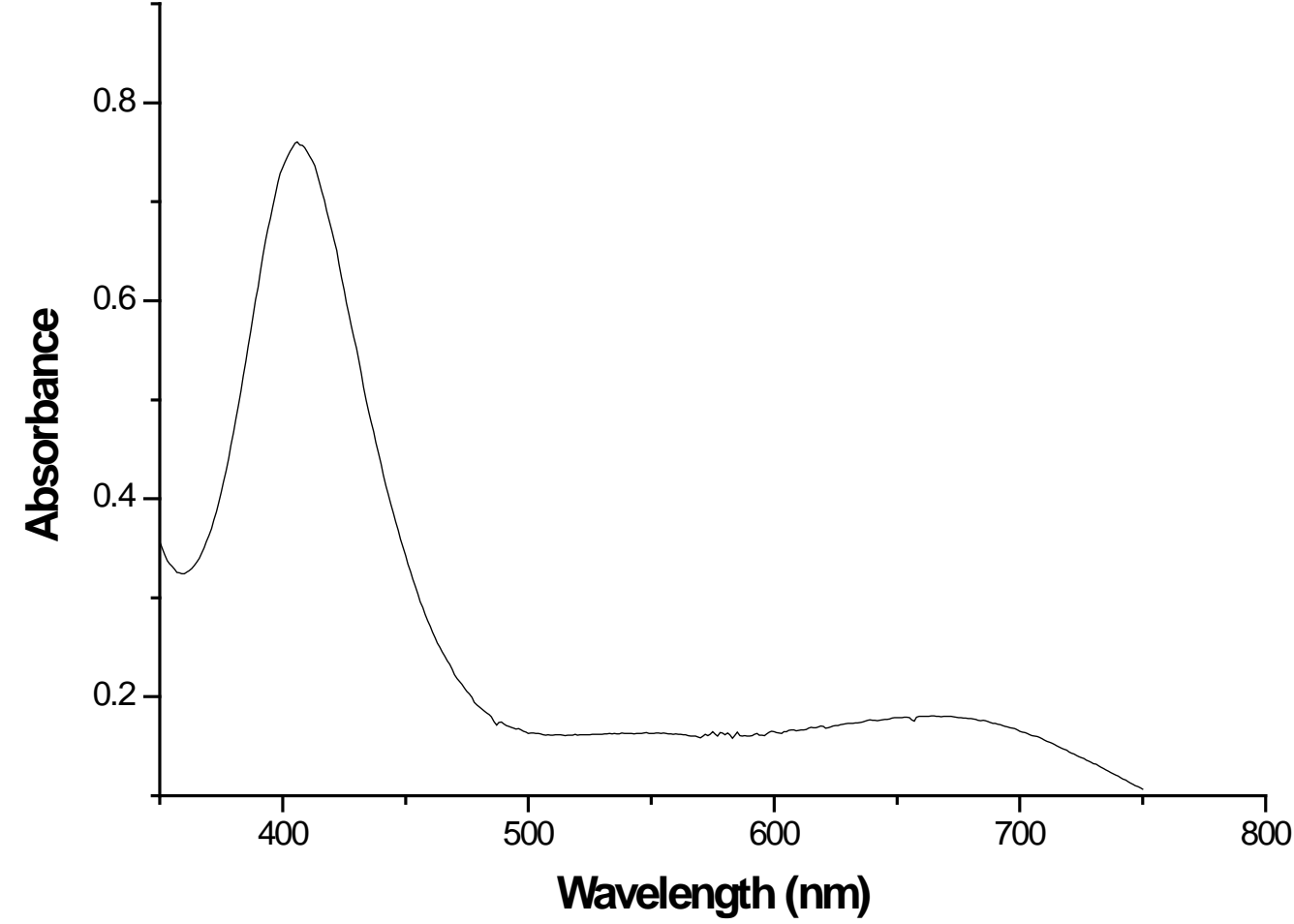

Figure 2. Absorption spectrum of the reaction product. Captopril final concentration $=1.61 \times 10^{-3} \mathrm{~mol}^{-1}$ optical path $=1 \mathrm{~cm}$. Measurements taken at $25^{\circ} \mathrm{C}$ against the reagent blank after stoppered to room temperature for $30 \mathrm{~min}$, as described in the recommended procedure.

Optimization of different experimental parameters and stability

The optimum conditions were established based on the development of maximum colour intensity and stability on variation of parameters affecting captopril oxidation and the coupled colour reaction with ammonium molybdate.

Using different concentrations of $\mathrm{H}_{2} \mathrm{SO}_{4}$, it was found that maximum colour intensity and stability were obtained by developing the reactions in $8.73 \mathrm{~mol} \mathrm{l}^{-1} \mathrm{H}_{2} \mathrm{SO}_{4}$, as described in the recommended procedure. At higher concentrations of $\mathrm{H}_{2} \mathrm{SO}_{4}$, the absorbance was found to decrease, whereas, below of this concentration the colour became unstable and the colour intensity diminished. Other acids were also studied for production

of colour and it was found that no colour reaction was produced with acids like acetic acid, phosphoric acid and nitric acid, whereas, with hydrochloric acid a very light yellow colour was obtained which was unstable.

Ammonium molybdate was used as a coour producing reagent. The adopted ammoniun molybda concentration (2\%) was found to be merient for prov sufereate cof this reagent was above or below of this concentration he absorbance was found to decrease.

The order of addition of the reactants recommended in the general procedure produced quantitative results. Any other order was found to produce deviant results and the colour intensity diminished.

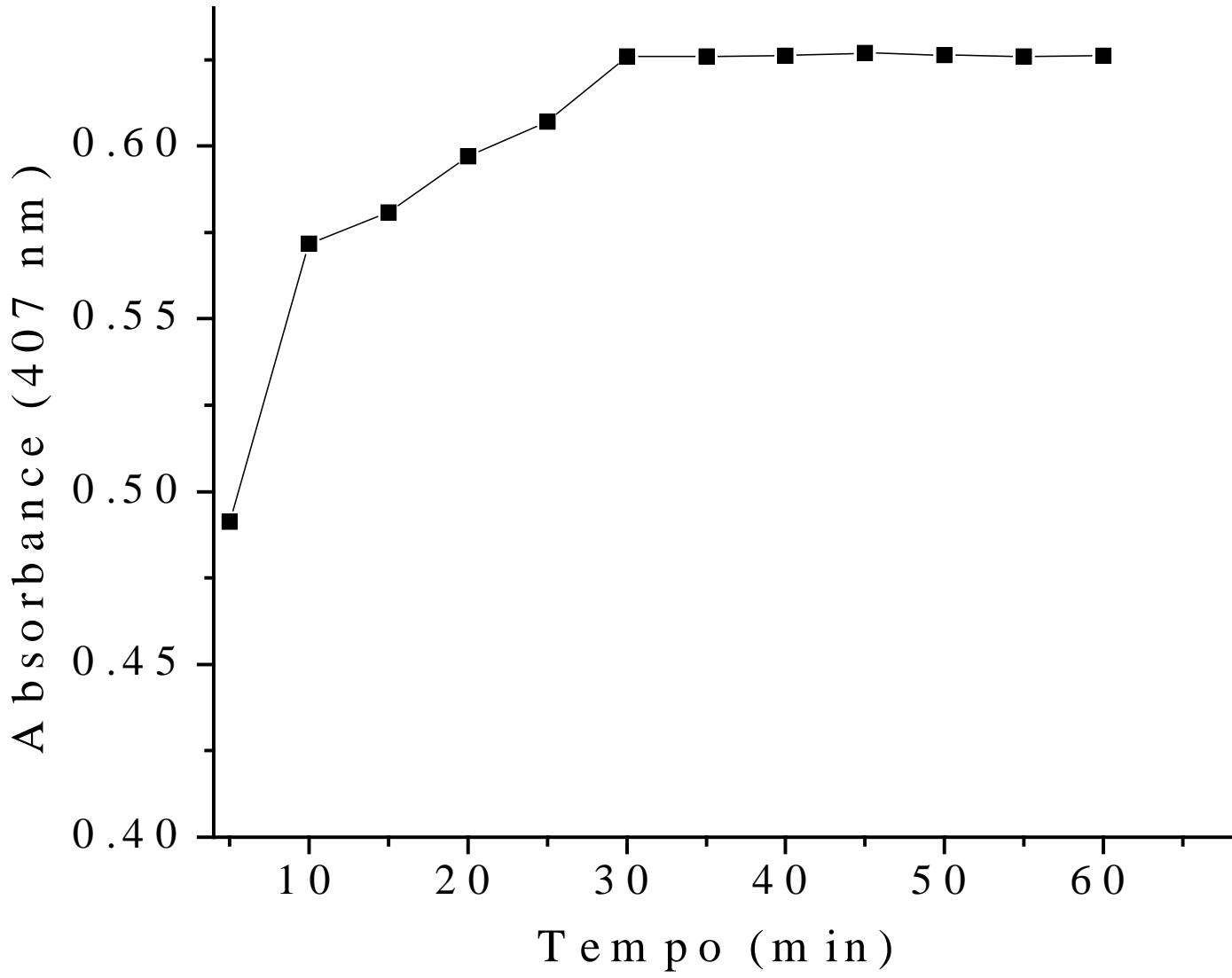

Figure 3. Effect of stoppered to room temperature $\left(25 \pm 1^{\circ} \mathrm{C}\right)$ time on the reaction. ${ }^{\mathrm{a}}$ Captopril concentration: $1.38 \times 10^{-3} \mathrm{~mol} \mathrm{l}^{-1} .{ }^{\mathrm{b}}$ Measurements taken at $407 \mathrm{~nm}$ against the reagent blank for reactants after stoppered to room temperature $\left(25 \pm 1^{\circ} \mathrm{C}\right)$ time (as described in the recommended procedure). ${ }^{\mathrm{c}}$ The absorbance remains unchanged standing for 1 day at $25^{\circ} \mathrm{C}$.

Analytical curves and sensitivity

The analytical curve (Figure 4) was obtained by the method of least squares from eleven points, each of which was the average of three determinations. The Beer's law is obeyed within $4.60 \times 10^{-4}-1.84 \times 10^{-3} \mathrm{~mol} \mathrm{l}^{-1}$ of CPT, in the fina solution, with an excellent correlation coefficien $\left(\mathrm{r}=0.9998\right.$; slope $=471.72 \pm 1.18 \mathrm{l} \mathrm{mol}^{-1} \mathrm{~cm}^{-1}$ and intercept $=-0.0162 \pm 0.0003)$. The limit of detection (3.SD ${ }^{\text {blank} / s l o p e ~ o f ~ c u r v e) ~ a n d ~ l i m i t ~ o f ~ q u a n-~}$ tification (10.SD blank/slope of curve) were $7.31 \mathrm{x}$ 
Table 1. Determination of CPT in commercial pharmaceutical preparations

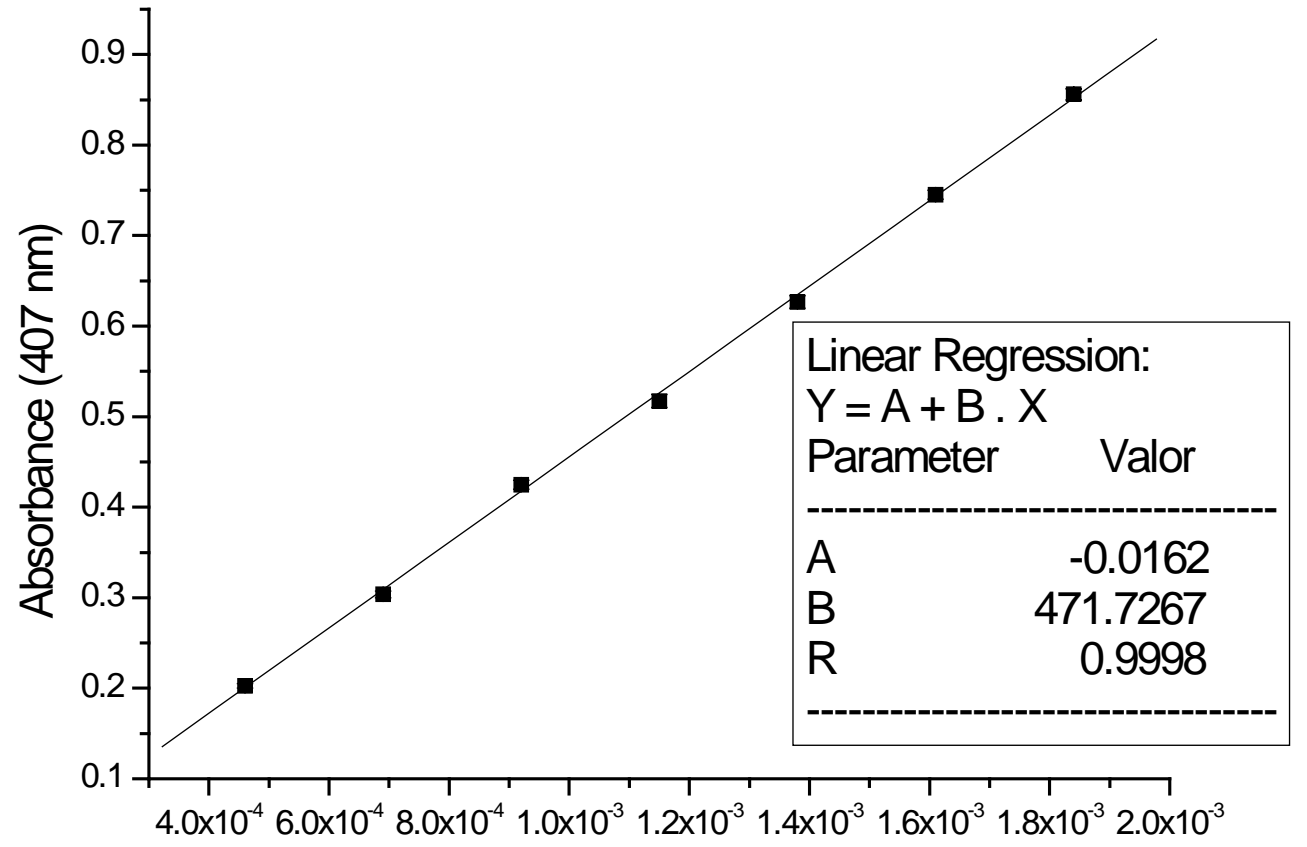

Concentration of CPT ( $\left.\mathrm{mol} \mathrm{I}^{-1}\right)$

Figure 4. Analytical curve for determination of captopril.

Effected of interferents

samples were prepared using the developed method. Then, the proposed method was successfully applied for CPT determination in six tablet formulations. The results, prented in favoluty with the official med Thare favorably with he officia method of the United States Pharmacopoeia [23] at 95\% confidence level. The results were subjected to a paired comparison test [52], the data of $t$ and $F$ ratios show no significant differences between the results of the proposed and the official methods, indicating very good accuracy and precision. mellose sodium, starch and magnesium were investigated using the developed The ratios of the concentrations of excipies substa concentrations of CPT to No interferences were observed in the presence of

\begin{tabular}{cccccccc}
\hline & & \multicolumn{5}{c}{ Proposed method } & \multicolumn{2}{c}{ Official method [23] } \\
\cline { 3 - 8 } Sample & $\begin{array}{c}\text { Label value } \\
{ }^{\mathrm{a}}\end{array}$ & Found $^{\mathrm{b}}$ & $\begin{array}{c}\text { R.S.D } \\
(\%)^{\mathrm{c}}\end{array}$ & $\begin{array}{c}t \text {-value } \\
(2.45)^{\mathrm{d}}\end{array}$ & $\begin{array}{c}F \text {-value } \\
(9.28)^{\mathrm{d}}\end{array}$ & Found $^{\mathrm{b}}$ & RSD (\%) \\
\hline A & 25.0 & $26.2 \pm 0.8$ & 3.0 & 0.40 & 2.56 & $26.0 \pm 0.5$ & 1.9 \\
B & 25.0 & $26.3 \pm 0.6$ & 2.3 & 0.92 & 4.00 & $26.2 \pm 0.3$ & 1.1 \\
C & 25.0 & $26.5 \pm 0.6$ & 2.2 & 0.56 & 2.25 & $26.3 \pm 0.4$ & 1.5 \\
D & 25.0 & $25.6 \pm 0.3$ & 1.2 & 0.61 & 9.00 & $25.6 \pm 0.1$ & 0.4 \\
E & 25.0 & $25.0 \pm 0.5$ & 2.0 & 1.37 & 6.25 & $26.6 \pm 0.2$ & 0.8 \\
F & 12.5 & $12.6 \pm 0.2$ & 1.6 & 1.18 & 4.00 & $12.8 \pm .0 .1$ & 0.8 \\
\hline
\end{tabular}

Label to content for tablets: $\mathrm{mg}_{\text {unit }}{ }^{-1}$.

${ }^{\mathrm{b}}$ Average value \pm standard deviation (SD) of four determinations.

Relative standard deviation (RSD) of four determinations.

${ }^{d}$ The figures between parentheses are the theoretical values of $t$ and $F$ at $P=0.05$

For further confirmation, the standard addition method was applied to test the reliability and recovery of the proposed method. The recovery studies were carried out after adding known quantities (100.0, 125.0 and $150.0 \mathrm{mg} \mathrm{l}^{-1}$ ) of the standard substance (pure drug) to the six preanalyzed formulations. The results presented in Table 2 show that the percentage average recoveries were found to be close to $100.0 \%$ of CPT from six commercial pharmaceutical preparations samples; the relative standard deviation (RSD) were within $0.1-1.0$. These results point out the accuracy $0.1-1.0$. These resuls point on the accury and precision of the method and the absence of ophotometric measurements. the substances tested.

Analytical applications, recovery and repeatability studies

In order to assess the utility of the presently developed method it was applied to the estimation of captopril in several pharmaceutical forms. The 


\begin{tabular}{|c|c|c|c|}
\hline Sample & Added (mg l-1) & Found $\left(\mathrm{mg} \mathrm{l}^{-1}\right)$ & Recovery (\%) ${ }^{a}$ \\
\hline A & $\begin{array}{l}100.0 \\
125.0 \\
150.0\end{array}$ & $\begin{array}{c}99.9 \\
127.3 \\
151.8\end{array}$ & $\begin{array}{c}99.9 \\
101.8 \\
101.2 \\
\mu^{\mathrm{a}}=100.9 \pm 1.0\end{array}$ \\
\hline B & $\begin{array}{l}100.0 \\
125.0 \\
150.0\end{array}$ & $\begin{array}{l}101.1 \\
126.0 \\
151.4\end{array}$ & $\begin{aligned} & 101.1 \\
& 100.8 \\
& 100.9 \\
& \mu^{\mathrm{a}=}=100.9 \pm 0.2\end{aligned}$ \\
\hline C & $\begin{array}{l}100.0 \\
125.0 \\
150.0\end{array}$ & $\begin{array}{l}100.1 \\
125.2 \\
150.4\end{array}$ & $\begin{aligned} & 100.1 \\
& 100.2 \\
& 100.3 \\
& \mu^{\mathrm{a}}= 100.2 \pm 0.1\end{aligned}$ \\
\hline D & $\begin{array}{l}100.0 \\
125.0 \\
150.0\end{array}$ & $\begin{array}{l}100.9 \\
125.9 \\
149.3\end{array}$ & $\begin{array}{c}100.9 \\
100.7 \\
99.5 \\
\mu^{\mathrm{a}=} 100.4 \pm 0.8\end{array}$ \\
\hline $\mathrm{E}$ & $\begin{array}{l}100.0 \\
125.0 \\
150.0\end{array}$ & $\begin{array}{l}100.2 \\
126.3 \\
148.9\end{array}$ & $\begin{array}{c}100.2 \\
101.0 \\
99.3 \\
\mu^{\mathrm{a}=} 100.2 \pm 0.8\end{array}$ \\
\hline $\mathrm{F}$ & $\begin{array}{l}100.0 \\
125.0 \\
150.0\end{array}$ & $\begin{array}{l}100.0 \\
125.1 \\
151.0\end{array}$ & $\begin{aligned} & 100.0 \\
& 100.1 \\
& 100.7 \\
& \mu^{\mathrm{a}}= 100.3 \pm 0.4\end{aligned}$ \\
\hline
\end{tabular}

average \pm standard deviation (SD) of three determinations.

To examine the repeatability of the procedure, replicate $(n=10)$ determinations were made on the same solution containing equivalent to 1.38 $\times 10^{-3} \mathrm{~mol} \mathrm{l}^{-1}$ of CPT $\left(300 \mathrm{mg} \mathrm{l}^{-1}\right)$. The relative standard deviation (RSD) at this concentration level was 1.2. This is good evidence of repeatability of the proposed method.

\section{Conclusion}

The proposed method results a simple, sensitive, inexpensive, precise and accurate analytical technique to determine captopril in commer- cial pharmaceutical preparations with satisfactory recoveries. Statistical comparison for the result of the proposed method with the official reported method indicates that there is no significant difference, at $95 \%$ confidence level, with regard to accuracy and precision. Additionally, it fulfills all the main demands of routine analysis as it is robust, has low instrumentation and operational cost in comparison to chromatographic methods and it doesn't request pretreatment of the sample.

When applied to the assay of various tablet dosage forms, its advantage is in that it does not

\section{Acknowledgements}

We would like to thank FUNDUNESP, CAPES and FAPESP Foundations (Brazil) for financial support.

Resumo: Um método simples, rápido e sensível para a determinação espectrofotométrica de captopril (CPT) em formulações farmacêuticas é proposto. Este método é baseado na reação de redução do molibdato de amônio, na presença de ácido sulfúrico, pelo grupo tiol do CPT, produzindo um composto verde $\left(\lambda_{\max } 407 \mathrm{~nm}\right)$. A lei de Beer é obedecida na faixa de concentração de $4,60 \times 10^{-4}$ a $1,84 \times 10^{-3} \mathrm{~mol} \mathrm{~L}^{-1}$ de CPT com um excelente coeficiente de correlação ( $\mathrm{r}=$ 0,9995). O limite de detecção e o limite de quantificação foram de $7,31 \times 10^{-6}$ e $2,43 \times 10^{-5} \mathrm{~mol}$ $\mathrm{L}^{-1}$ de CPT, respectivamente. O método proposto foi aplicado com sucesso na determinação da dos excipientes comos pelo método proposto foram comparados favoravelmente com aqueles obtidos pelo método oficial relatado em um nível de $95 \%$ de confiança.

Palavras-chave: Captopril, determinação espectrofotométrica, molibdato de amônio.

\section{References}

[1] K. Fiorey, Analytical Profiles of Drugs Substances, vol. 11, Academic Press, New York, 1982, p. 81

2]A.G. Gilman, J.G. Hardman, L.E. Limbird, P.B. Molinofr, R.W. Ruddon (Eds.), The Pharmacological Basis (3) (3) (1991) 176 .

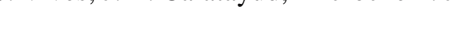
4] X.R. Zhang, W.R.G. Baeyens, G. Van Der Weken, A.C. K. Nakashima, Anal. Chim. Acta 303 (1995)

I5] Z.D. Zhang, W.R.G. Beyens, X.R. Zhage, T. Van Der Weken, J. Phom, W.R.G. Baid And 14 (8-10) (1996) 939.

[6] Z. Xinrong W.R.G. Baeyens, G. Van Der Weken A.C. Calorinos, K. Nakashima, J. Pharm. Biomed, Anal. 13 (1995) 425.

mou, D.G. Themelis, G. Theodoridis, P.D.

y, O.A. Razak, S.F. Belal, R.S. Bakry, J. 21 (1999) 439

9] M.A. El Reis, F.M. Abou Attia, I.M.M. Kenawy, J. Pharm. Biom. Anal. 23 (2000) 249.

[10] T. Mirza, H. S. Tan, J. Pharm. Biomed. Anal. 25 (2001)

Ecl. Quím., São Paulo, 35 - 3: 179 - 188, 2010
[11] R.J. Kok, J. Visser, F. Moolenaar, D. Zeeuw, D.K.F. Meijer, J. Chromatogr. B 693 (1) (1997) 181.

[12] A. Jankowski, A. Skorek, K. Krzyrśḱko, P.K. Zarzycki, R.J. Ochocka, H. Lamparczyk, J. Pharm. Biomed. Anal. 13 (1995) 655.

S. Sypniewski, E. Bald, J. Chromatogr. A 729 (1996)

[14] E. Bald, S. Sypniewski, Fresenius J. Anal. Chem. 358 (4) (1997) 554.

[15] V. Cavrini, R. Gatti, A.M. Dipreta, M.A. Raggi, Chromatographia 23 (9) (1987) 680.

16] V. Cavrini, R. Gatti, V. Andrisano, R. Gatti, Chromatographia 42 (9-10) (1996) 515.

17] G. Favaro, M. Fiorani, Anal. Chim. Acta 332 (2-3) (1996) 249

Wu, S.H. Chen, S.M. Wu, Anal. ett. 28 (8) (1995) 1465.

源 anta 46 (1) (1998) 75.

Staden, H.Y. Aboul-Enein, Anal. him. Acta 411 (2000) 51.

B.S.F. Band, J. Pharm. Biomed. Ana. 30 (3) (2002) 547.

M. E., Aboul - Enein, H.Y, Anal. Lett. 18 (B20) (1985) 2591. 
[23] United States Pharmacopeial Convention, The United States Pharmacopeia: The national formulary: captopril, $24^{\text {th }}$ edn., Revision. Rockville, 2000, p. 296.

[24] M.E. Mohamed, H.Y. Aboul-Enein, E.A. Gad-Kariem, Anal. Lett. 16 (B1) (1983) 45.

[25] A.M. El-Brashy, Acta Pharm. Hung. 65 (3) (1995) 91.

[26] [26] R.I. Stefan, J.F. Van Staden, H.Y. Aboul-Enein, Talanta 48 (5) (1999) 1139.

[27] A.M. Pimenta, A.N. Araújo, M.C.B.S.M. Montenegro, Anal. Chim. Acta 438 (2001) 31.

[28] P.R.S. Ribeiro, A.O. Santini, H.R. Pezza, L. Pezza, Eclét. Quim. 28 (1) (2003) 39.

[29] S. Hillaert, W. Van Den Bossche, J. Pharm. Biomed. Anal. 21 (1) (1999) 65.

[30] K. Nikolic, K. S. Valasevic, Pharmazie 44 (2) (1989) 155. [31] K. Nikolic, K.S. Valasevic, Acta Pol. Pharm. 48 (1 - 2) (1991) 5.

[32] K. Sarna, Z. Fijalek, Chem. Anal. (Warsaw) 42 (3) (1997) 425.

[33] Ribeiro, P.R.S.; Santini, A.O.; Pezza, H.R.; Pezza, L.; Eclet. Quim. 2003, 28, 39.

[34] H.F. Askal, Talanta 10 (1991) 1155.

[35] F.M. Ashour, F.M. Salama, M.A.E. Aziza, J. Drugs Res. $19(1-2)(1990) 323$.

[36] M. I. Albero, C. Sánchez-Petreño, M. S. Garciá, V. Ródenas, J. Pharma. Biom. Anal. 11 (1993) 887.

[37] T. Jovanivic, B. Stanovic, Z. Koricanac, J. Pharm. Biomed. Anal. 13 (3) (1995) 213.

[38] P.D. Tzanavaras, D.G. Themelis, A. Economou, G. Theodoridis, Talanta, 57 (2002) 575.

[39] N.M. Sanghavi, M.M. Samarth, R. Matharu, P.S. Indian Drugs 28 (4) (1991) 189.

[40] C.S.P. Sastry, A. Sailaja, T.T. Rao, Pharmazie 46 (6) (1991) 465.

[41] R. Karlicek, P. Solich, Pharmazie 53 (8) (1998) 549.

[42] [42] S. M. El-Ashry, F. A. Ibrahim, Anal. Lett. 25 (9) (1992) 1657.

[43] [43] B. Morelli, P. Peluso, Anal. Lett. 18 (15) (1985) 1865.

[44] [44] S. M. Sultan, Analyst, 111 (1) (1986) 97.

[45] [45] M. M. Abdel Khalek, M. S. Mahrous, Talanta 31 (8) (1984) 635.

[46] [46] P. B. Issopoulos, J. Pharm. Biomed. Anal. 6 (1) (1988) 97.

[47] [47] P. B. Issopoulos, Analyst 113 (7) (1988) 1083.

[48] [48] M. Stan, V. Dorneanu, G. Ghimicescu, Talanta 24 (2) (1977) 140.

[49] [49] H. Sanke Gowda, P. G. Ramappa, A. N. Nayak, Anal. Chim. Acta 108 (6) (1979) 277.

[50] [50] P. Timmins, I.M. Jackson, Y.I. Wang, Int. J. Pharm. 11 (4) (1982) 329.

[51] [51] Long, G.L.; Winefordner, J.D.; Anal. Chem. 1983, $55,712$.
[52] [52] J.C. Miller, J.N. Miller, Estadística para Química Analítica, 2nd edn.; Addison-Wesley Iberoamericana, Delaware, E.U.A., 1993, p.209. 